\title{
Fighting Fire with Fire? Inequality, Populism and Voter Turnout
}

\author{
Hanna Schwander $\cdot$ Dominic Gohla $\cdot$ Armin Schäfer
}

Published online: 30 April 2020

(C) The Author(s) 2020

\begin{abstract}
In this article, we ask whether the presence of populist parties influences the negative effect of income inequality on voter turnout. A number of studies have shown that voter turnout is lower in unequal countries. In particular, citizens with fewer resources abstain at higher rates. Since populist parties seek to mobilize these groups, their success could lead to higher and less unequal turnout rates. To assess empirically whether this holds true, we analyzed a dataset encompassing data on 296 national parliamentary elections in 31 European countries between 1970 and 2016. The results show that there is neither a direct nor an indirect effect of populism on voter turnout. In elections with more successful populist parties, voter turnout was not significantly higher than in other elections. Higher vote shares of populist parties also do not mitigate the negative impact of income inequality on voter turnout. Finally, there does not seem to be a difference between elections with high left-wing or right-wing populist parties' success. Neither variant of populism alters the relationship between inequality and turnout.
\end{abstract}

Keywords Voter turnout · Populism · Inequality · Participation · Political sociology

H. Schwander · D. Gohla

Humboldt-Universität Berlin, Unter den Linden 6, 10099 Berlin, Germany

A. Schäfer $(\bowtie)$

Institut für Politikwissenschaft, Westfälische Wilhelms-Universität,

Scharnhorststraße 100, 48151 Münster, Germany

E-Mail: aschaefer@uni-muenster.de 


\section{Feuer mit Feuer bekämpfen? Ungleichheit, Populismus und Wahlbeteiligung}

Zusammenfassung In diesem Beitrag wird die Frage gestellt, ob populistische Parteien den negativen Zusammenhang zwischen Einkommensungleichheit und der Höhe der Wahlbeteiligung beeinflussen. Eine Reihe von Studien hat gezeigt, dass die Wahlbeteiligung in ungleichen Ländern niedriger ausfällt. Vor allem Bürgerinnen und Bürger mit weniger Ressourcen bleiben dort häufiger am Wahltag zu Hause. Da populistische Parteien darauf abzielen, jene Gruppen zu mobilisieren, die eine höhere Wahrscheinlichkeit haben, nicht zu wählen, könnte ihr Erfolg zu einer höheren und weniger ungleichen Wahlbeteiligung führen. Um diesen möglichen Zusammenhang empirisch zu überprüfen, wurde ein Datensatz von Informationen über 296 Parlamentswahlen in 31 europäischen Ländern für den Zeitraum von 1970 bis 2016 analysiert. Die Ergebnisse zeigen jedoch, dass weder ein direkter noch ein indirekter Zusammenhang zwischen Populismus und Wahlbeteiligung besteht. Schneiden populistische Parteien besonders gut ab, fällt die Wahlbeteiligung nicht höher aus. Hohe Stimmenanteile dieser Parteien mildern auch nicht den negativen Zusammenhang zwischen Ungleichheit und Wahlbeteiligung ab. Schließlich konnten auch keine unterschiedlichen Effekte zwischen links- und rechtspopulistischen Parteien gefunden werden. Keine der beiden Varianten verändert die grundlegenden Zusammenhang zwischen Einkommensungleichheit und der Höhe der Wahlbeteiligung.

Schlüsselwörter Wahlbeteiligung · Populismus · Ungleichheit · Participation · Politische Soziologie

\section{Introduction}

We live in times of societal turmoil and worrisome political developments. In this article, we link two of the most studied of these developments: the rise of economic inequality and its impact on democracy, and the rise of populism. Scholars and policy-makers increasingly worry about the unequal distribution of income (OECD 2008, 2011; Smeeding 2005), wealth (Piketty 2014), and economic risks more generally (Hacker et al. 2013; Schwander 2019) and their effect on democracy. Studies provide ample evidence that democracy is less responsive to the concerns of the less affluent (Bartels 2008; Elsässer et al. 2017; Giger et al. 2012; Gilens 2005), which consequently leads to lower participation, in particular among disadvantaged voter groups (Mahler 2002; Schäfer and Schwander 2019; Solt 2008). The rise of populism is another of the most discussed phenomena in contemporary political science. A wealth of studies examine the rise and success of populist parties across the globe (Abou-Chadi and Krause 2018; Akkerman et al. 2013; Bornschier 2012; Manow 2018; van Hauwaert and van Kessel 2018), individual-level determinants for populist support (Arzheimer 2018; Burgoon et al. 2019; Ivarsflaten 2007; Rooduijn 2018), and the effect on other parties' ideological positions or governments' output (Bale et al. 2009; Lutz 2019; Röth et al. 2018). 
Some authors seem to suggest that to fight the fire of political inequality, it might be necessary to heat up the fire of populism (Mouffe 2018). For example, Weyland (2001, p. 14) argues that populists win support "by 'representing' people who feel excluded or marginalized from national political life and by promising to rescue them from crises, threats, and enemies." Mudde and Rovira Kaltwasser (2017, p. 51) note that "[...] populist political parties use populism to challenge the establishment and to give voice to groups that feel unrepresented." Similarly, Mény and Surel (2002, p. 11) maintain that "[...] feelings of powerlessness, of not being able to voice dissatisfaction effectively, of not being able to make oneself heard, are all fertile ground for populist parties." In addition, among the "positive effects" of populism for democracy that Mudde and Rovira Kaltwasser (2012, p. 21) enumerate, the mobilization and improved representation of excluded sections of society figure prominently. Those who see populism as a corrective for democracy often assume that populist parties increase political equality. In this article, we seek to test this assumption empirically.

In what follows, we analyze whether populist parties moderate the effect of inequality on turnout because they mobilize voter groups that often refrain from participating in politics in unequal societies. We test whether both left-wing and right-wing populists have a similar effect because both party groups seek to mobilize the disenchanted and dissatisfied citizens (Schumacher and Rooduijn 2013; van Hauwaert and van Kessel 2018). Our examination of these arguments is based on a self-compiled dataset encompassing data on 296 national parliamentary elections in 31 European countries between 1970 and 2016. Based on these data, we do not find evidence that populist parties increase electoral participation or diminish the negative effect of income inequality on voter turnout.

The reminder of the paper is structured as follows: We first review the literature on the relationship between economic inequality and electoral participation before developing our argument on how populist parties might potentially influence the effect of inequality on democracy. We then proceed to describing the data, the measurement of our variables, and the empirical approach. The empirical analysis tests several hypotheses, and the final section provides our conclusions.

\section{Theoretical Background}

\subsection{Theoretical Arguments On the Inequality-participation Relationship}

In this section, we review the literature on the inequality-participation relationship, with the key message being that economic inequality has a negative impact on turnout, in particular among disadvantaged social groups. From a conflict perspective, inequality might actually increase voter participation. In the context of a widening income gap between the rich and the poor, the poor might have stronger incentives to use their voting power to "soak the rich" (Shapiro 2002) and to increase redistribution. Implicitly or explicitly, the theoretical workhorse of these studies is the Meltzer-Richard model (1981) that would make us assume that it is rational to participate in elections if the stakes are high — and they are particularly high in 
unequal countries (Brady 2004)—because after all, democracy distributes voting rights more equally than the market distributes income. Democracy provides people with means to voice their disagreements, organize collectively, and overturn elites democratically, which is why economic inequality may also stimulate democratic engagement (Gurr 1970; Oliver 2001).

While there is some empirical support for this argument (Brady 2004; Davies and Falleti 2017; Oliver 2001), the most recent studies provide evidence for a negative effect of inequality on turnout, in particular among disadvantaged groups in societies (Schäfer and Schwander 2019; Solt 2008). ${ }^{1}$ Apart from lower political interest and fewer resources at their disposal (Brady et al. 1995; Verba 1996), the perception of not being represented and of subjective political impotence, both sentiments increasing with growing economic inequality, can make abstention to appear a rational choice. High levels of income inequality signal to poorer citizens that their concerns are likely to be neglected, whereas the better-off learn that they get what they want and they have other, possibly more effective, means at their disposal-lobbying, donations, direct contact with decision-makers (Bartels 2008) - to make their voices heard. In addition, the poor possess relatively fewer resources to invest in politics, while the rich find it easier to dominate the political agenda (Schattschneider 1960). In unequal societies, the preferences and interests of the poor and the rich diverge more strongly (Gallego 2015; Peters and Ensink 2015), which makes the exclusion of their issues from the political debates even more problematic for the poor.

Developments in party politics exacerbate the exclusion of the disadvantaged from politics. Traditionally, the lower strata were politically represented by left parties, supported by powerful trade unions that mobilized the working class and other disadvantaged groups (Huber and Stephens 2001). The organizational power of trade unions has since declined, and insights from the dualization literature teach us that trade unions today represent more privileged labor market insiders than labor market outsiders (Fervers and Schwander 2015; Lindbeck and Snower 2001; Mosimann 2017; Rueda 2007). As to the political representation of disadvantaged groups, changes are even more pronounced. The main parties of the left, the social democratic parties, are by no means "working class" parties (anymore), in the sense of relying on the working class as their core voters. Confronted with declining electoral relevance of their core constituency on account of social and economic changes, these parties have successfully attracted specific parts of the educated middle class, leading to a "middle-class shift" in their electoral coalition (Evans and Tilley 2017; Gingrich and Häusermann 2015; Häusermann 2018; Rennwald and Evans 2014). This has implications for the programmatic orientation of social democratic parties, not only in their bread-and-butter area of distributive politics, where they reform the welfare state in a way that is often perceived as a move to the center (Anderson and Beramendi 2011; Karreth et al. 2013), but also regarding sociocultural policies where social democratic parties have adopted more progressive positions in line with the preferences of their middle-class electorate (Abou-Chadi and Wagner 2019; Kitschelt 1994).

\footnotetext{
${ }^{1}$ See, however, Stockemer and Scruggs (2012), who find no evidence for a negative effect of income inequality.
} 


\subsection{Populism, Inequality and Turnout}

This is where populist parties enter the stage. They might influence voter turnout through two potential mechanisms. The first mechanism centers on the support base of populist parties that mobilizes those disadvantaged groups that are dissatisfied with politics (Arzheimer 2009; Kriesi 2008a; Kriesi et al. 2008b; Lubbers et al. 2002; Werts et al. 2012). Second, populist parties might increase the responsiveness of the entire party system by politicizing issues that were previously not debated and by forcing established parties to change their positions on these issues (Bornschier 2012; Lutz 2019).

Let us elaborate on the first mechanism. The literature advances two arguments about the motivations to cast a populist vote: First, in versions of spatial voting models, vote choices are based on ideological proximity. The literature vigorously debates the issues that drive support for populists. Some scholars emphasize the relevance of sociocultural value preferences for the populist right vote. Among these values, attitudes toward immigration stand out as the single most important determinant, in particular if immigration originates from ethnically different and, in recent times, also religiously different, primarily Muslim countries (Arzheimer 2018; Ford et al. 2012; Goerres et al. 2018; Lubbers et al. 2002; Rydgren 2008). The well-known "modernization losers" account tethers the value preferences to specific occupational groups, developing an argument about why the losers of modernization-that is, the less educated and the lower social strata - exhibit such anti-immigration, nationalist, and ethnocentric preferences (Bornschier 2010; Hainmueller and Hiscox 2007; Kriesi 1998; Kriesi et al. 2008b; Oesch 2008). ${ }^{2}$ Recent variants emphasize the relevance of subjective economic insecurity and relative decline rather than absolute deprivation as a motivation to cast a right-wing populist vote (Burgoon et al. 2019). Others emphasize competition for scarce resources as the motivation (Manow 2018; Schwander and Manow 2017). In essence, this school of thought argues that proximity between specific issue preferences and party positions pulls voters to support a specific populist party.

In the "protest vote" perspective, by contrast, voters are considered not in favor of a specific (populist) party, but they want to express their dissatisfaction with other (nonpopulist) parties. Most prominently, the unresponsiveness of established parties to the concerns and grievances of populist voters pushes them toward a populist vote rather than the specific policy stances of the populist parties. The ideological convergence of established parties and the resulting disenchantment with the workings of democracy are crucial in this argument (Kriesi et al. 2008b). Populist parties are most likely to benefit from the anti-elite sentiments caused by an unresponsive political elite because they present themselves as challengers to the "political establishment" and as "political outsiders" (Akkerman 2016; Krause and Wagner 2019). There is ample evidence for the relevance of both anti-elite sentiments and disaffection with democratic actors and institutions to lead to casting a populist vote, for both left

\footnotetext{
${ }^{2}$ For Norris and Inglehart (2019), this is mainly a conflict between older and younger generations. As older social conservatives lose their hegemonic position, they turn to parties that rally against value change and favor more traditional cultural positions.
} 
and right variants of populism (Hooghe et al. 2011; Ivarsflaten 2007; Rooduijn and Akkerman 2015; Schumacher and Rooduijn 2013; Visser et al. 2014), although not all populist parties benefit equally from these sentiments. Once antiestablishment parties become part of the establishment by taking part in governments, they no longer capitalize on such sentiments (Krause and Wagner 2019). ${ }^{3}$

The second mechanism relates to the impact that populist parties have on political competition. The literature has long emphasized the relevance of party competition for turnout in general (Blais 2006) and for the relationship between turnout and inequality specifically by arguing that a higher number of parties increases electoral turnout because it boosts the programmatic offer and incentivizes parties to mobilize voter groups beyond the median voter. This holds in particular for the main party of the left, which is much more concerned with mobilizing their lower-skilled voter segments if a left competitor is fishing in the same pond (Anderson and Beramendi 2011; Schwander 2019). Hence, the structure of party competition is able to alleviate the impact of inequality on turnout if several left parties mobilize the disadvantaged voter segments. Populist parties are of crucial relevance here, although they have not been studied in the voting or the Comparative Political Economy (CPE) literature. Populist parties do not only represent a challenger to established parties along the lines of arguments presented above, but they might in addition impact the responsiveness of the political system in specific ways that are relevant for the inequality-participation nexus. Under specific circumstances, populist parties increase the responsiveness of political systems by politicizing new issues. Populist parties also repoliticize political competition if established parties have converged too much on relevant issues (Mouffe 2005). By politicizing new issues and political conflicts, populist parties give elections "meaning," which has been shown to matter for turnout (Cox 1999; Selb 2008). Important for our argument is that populist parties find their supporters in particular among those social groups that are most likely to feel politically powerless (Mény and Surel 2002) and therefore refrain from participating in politics. In addition, the electoral threat that populist parties start to represent for established parties causes them to adapt their positions (Abou-Chadi and Krause 2018; Bale 2003; Bale et al. 2009; Bornschier 2012), which increases the responsiveness of party systems.

Do these arguments equally apply to left-wing and right-wing populist parties? While we will examine this empirically, we would argue yes from a theoretical point of view. Left-wing and right-wing populist parties share some positions, albeit for very different reasons. Both tend to be in favor of demarcation (Burgoon 2012; Halikiopoulou et al. 2012), skeptical of far-reaching European integration (Hooghe et al. 2004), and focus on the message that ordinary people are neglected, exploited, or corrupted by the elite (Mudde 2004). Left-wing and right-wing populism differ in the ideological framework to which they attach their elite critique-democratic socialism and nativism, respectively (Betz and Habersack 2020; Mény and Surel 2002; Mudde and Rovira Kaltwasser 2013). Reflecting these similarities of the parties' ideological profiles, the profiles of their voters are found to be comparable

\footnotetext{
3 It is important to note that neither the "push" nor the "pull" factors are driven predominantly by levels of income inequality.
} 
as well: Populist left and right voters come from similar socioeconomic backgrounds and share political desires and discontents (Lubbers and Scheepers 2007; Visser et al. 2014). The populist left is a viable option for disenchanted citizens in unequal societies as it has a tradition of criticizing the unequal outcomes of capitalism and of advocating a redistribution of income and opportunities by profound reforms in the political and economic systems (Mudde 2004). Indeed, left-wing and right-wing populist voters share similar class backgrounds, but voters of the populist left tend to be more highly educated than voters for the populist right (Lubbers and Scheepers 2007; Visser et al. 2014) and to embrace cosmopolitan values, whereas right-wing populist voters exhibit nativist values (Rooduijn et al. 2017).

In sum, populist parties could moderate the impact of inequality on turnout if they mobilize groups who are dissatisfied with politics and feel unrepresented by the established political elite. In that sense, populism might function as a "democratic corrective" and increase the responsiveness of party systems if populist parties give voice to previously unrepresented social groups (Mudde and Rovira Kaltwasser 2017 , p. 83). As a result, populist parties could, the argument goes, increase citizens' electoral participation by attracting previous nonvoters. ${ }^{4}$ A second effect of the rise of populist parties on aggregate turnout is possible: The upsurge of populism might provoke a "countermobilization" of drawing "antipopulist nonvoters" to the polls (Bornschier 2018). Indeed, right-wing populist parties tend to motivate highly educated and politically interested citizens to go to the polls (Immerzeel and Pickup 2015)_-voters who are most likely to be opponents of populist right-wing parties (Oesch and Rennwald 2010).

Based on the arguments outlined above, we empirically tested the following three hypotheses: All else being equal, the higher the vote share of populist parties, the higher the level of turnout (H1). The electoral success of populist parties moderates the effect of income inequality on aggregate turnout (H2), and both left-wing and right-wing populist parties moderate the effect of inequality on turnout (H3).

One additional note: The mechanisms discussed above pertain to the electoral strength of the populist parties rather than to their existence alone. The larger the share of previously alienated and disappointed voters who are mobilized by populist parties, the more the depressing effect of inequality on aggregate turnout should be attenuated. Similarly, the effect of the rise of populism is likely to depend on the electoral strength of populist parties rather than on the entry of populist parties alone. Established parties, for instance, start to adapt on issues relevant for populist voters only when populist parties have substantial electoral support, as Bale et al. (2009) show convincingly for the social democratic positions on immigration and integration during the rise of right populist parties in Northern Europe. In our study, we will therefore focus on the electoral strength of populist parties rather than on their existence.

\footnotetext{
4 In contrast to this assumption, Anduiza et al. (2019) show that even though populist attitudes increase political engagement, they have no effect on electoral participation.
} 


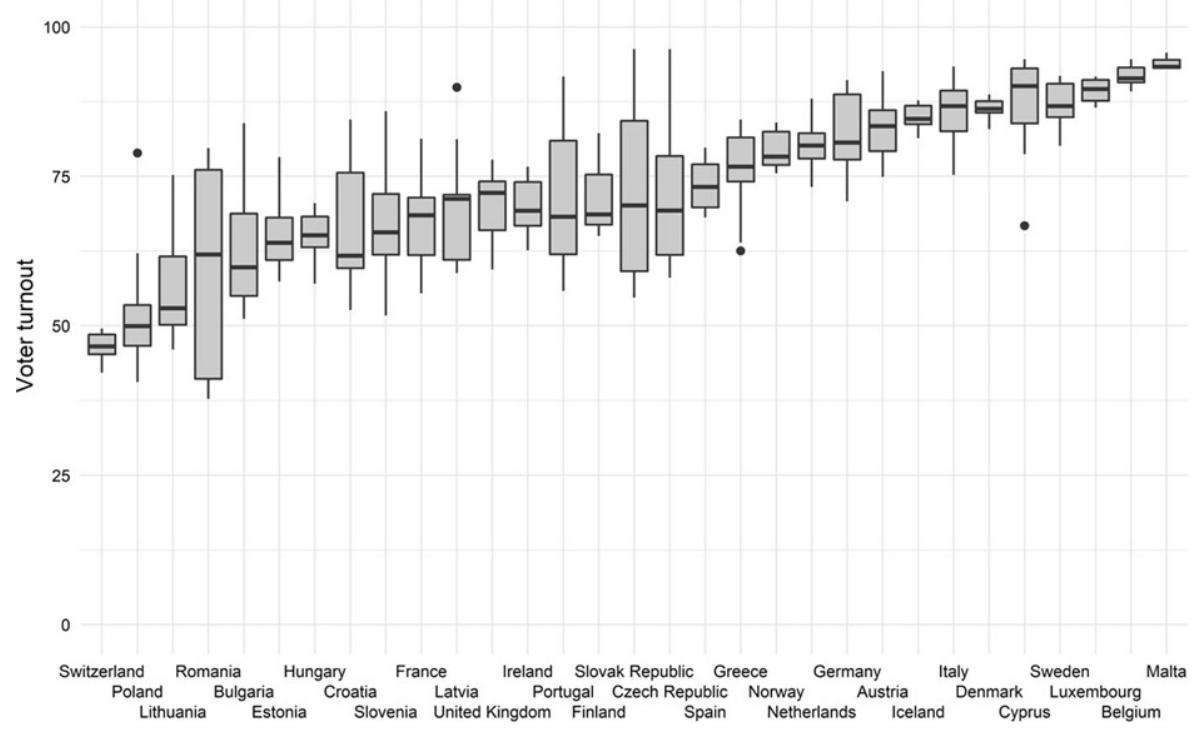

Fig. 1 The spread of voter turnout in 31 countries. Data from International Institute for Democracy and Electoral Assistance

\section{Variables, Measurement, and Data}

To test the argument, we analyzed the interaction between the effects of inequality and populist vote shares on voter turnout at the macro level. We used a self-compiled dataset encompassing data on 296 national parliamentary elections in 31 European countries between 1970 and 2016. Because of data availability, our panel was unbalanced, containing between three elections in the case of Malta and 15 elections in the case of Portugal, with a median number of nine elections. For each election, the dataset includes information on voter turnout, the vote share of populist parties, inequality as measured by the Gini coefficient, socioeconomic indicators, and information on the respective institutional setting. The following paragraphs provide additional information on the data and variables deployed in the analysis.

Voter Turnout The dependent variable in all subsequent analyses was voter turnout. The data were drawn from the publicly available voter-turnout database from the International Institute for Democracy and Electoral Assistance (International IDEA). ${ }^{5}$ Figure 1 shows the distribution of turnout in all countries included in subsequent analyses. The countries are ordered in line with the average turnout rate. As one can see, there is a lot of variation between and within countries. There are consistently high levels of voter turnout in Malta, Luxembourg, and Belgium; the latter two adhering to a strong version of compulsory voting. Cyprus and Italy (used to) make voting mandatory, too, but the level of enforcement is weaker. Switzerland, with the widespread use of direct democracy, has consistently low levels of voter

\footnotetext{
5 https://www.idea.int/data-tools/data/voter-turnout
} 
Table 1 Summary statistics on populist vote share

\begin{tabular}{llllll}
\hline & $\begin{array}{l}\text { Observations } \\
\text { (election-years) }\end{array}$ & $\begin{array}{l}\text { Mean } \\
(\%)\end{array}$ & $\begin{array}{l}\text { Standard } \\
\text { deviation }\end{array}$ & Minimum & Maximum \\
\hline Populist vote share & 296 & 9.6 & 13.33 & 0 & 69.4 \\
$\rightarrow$ Vote share $>0$ & 193 & 14.7 & 14.05 & 0.44 & 69.4 \\
Right-populist vote share & 296 & 7.5 & 11.60 & 0 & 69.4 \\
$\rightarrow$ Right-populist vote share $>0$ & 157 & 14.2 & 12.64 & 1 & 69.4 \\
Left-populist vote share & 296 & 2.1 & 5.92 & 0 & 44.4 \\
$\rightarrow$ Left-populist vote share $>0$ & 63 & 9.7 & 9.51 & 0.44 & 44.4 \\
\hline
\end{tabular}

turnout. Many of the younger East European democracies also show low levels of turnout.

Populist Parties To identify populist parties, we relied on the adequately named PopuList by Rooduijn et al. (Rooduijn et al. 2020), a publicly available peer-reviewed list providing a classification of parties as populist, far right, far left, or Eurosceptic for 31 European countries. ${ }^{6}$ Eighty-two parties are categorized as populist. We combined this dataset with ParlGov ${ }^{7}$ data on party vote shares in national parliamentary elections and party placement on a 10-point left-right scale (Döring and Manow 2019), using the latter to designate parties as left-populist or rightpopulist, based on a cut-off score of $5 .{ }^{8}$ We then aggregated the vote shares of all left-populist and right-populist parties running in a given election into a single leftpopulist, right-populist, and total populist electoral share for each election. Table 1 shows the resulting distribution of these variables.

Populist parties were present in around two-thirds of the 296 elections in the sample. Around half of the elections had one or more right-populist parties competing, while left-populist parties were present in roughly a fifth of the elections. Rightpopulist parties were significantly more successful where they competed, gaining an average vote share of $14.7 \%$ as opposed to left-populist parties' average vote share of $9.7 \%$. As clearly visible in Fig. 2, for both left-populists and right-populists, electoral results have increased over time, particularly since the early 2000s.

Inequality As a measure of inequality, we used net Gini scores for each election year. These data were drawn from the Standardized World Income Inequality Database (SWIID; Solt 2019). ${ }^{9}$ The Gini index describes the distribution of income in a given geographical unit, in our case within countries, where a higher Gini corresponds to greater income inequality. We utilized the net Gini, also referred to as

\footnotetext{
6 https://popu-list.org

7 http://www.parlgov.org

8 As a robustness test, we further tested a three-category classification, using cut-off scores of below 3.3 for left-populist parties, between 3.3 and 6.6 for center-populist parties, and above 6.6 for right-populist parties. While this in some cases resulted in observation counts to draw meaningful insights from, the results are largely identical with those of the two-category classification.

9 https://fsolt.org/swiid
} 


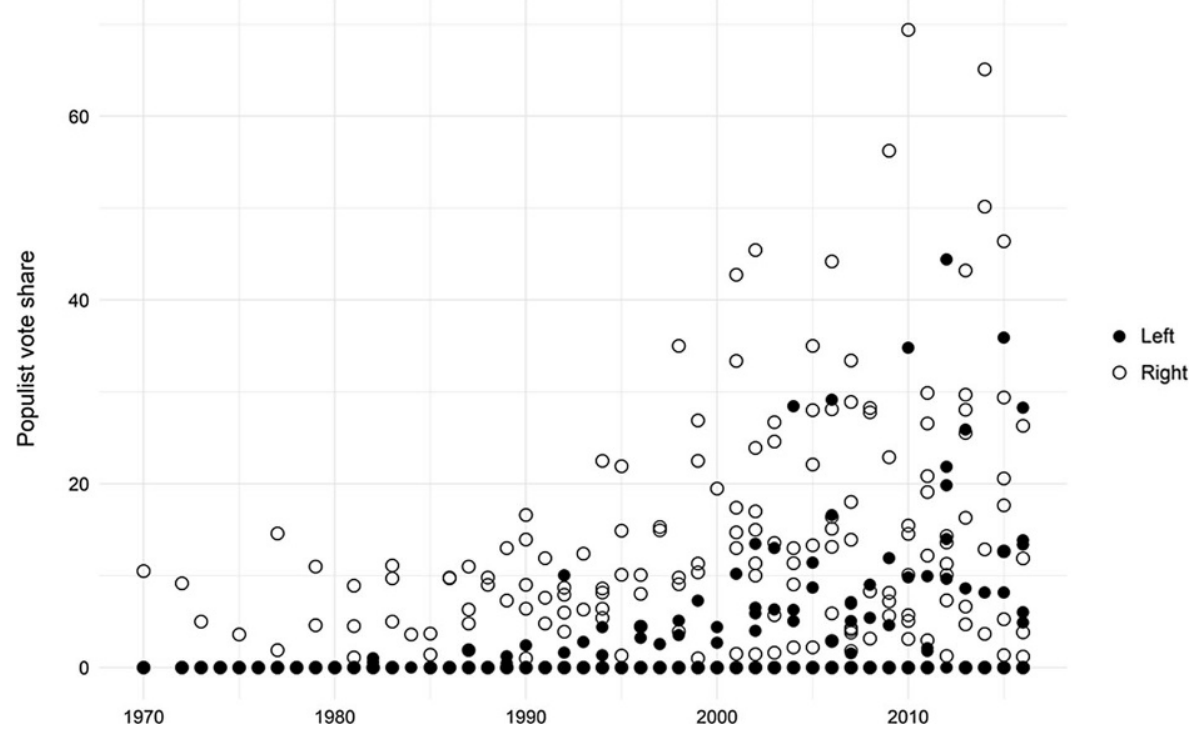

Fig. 2 Populist vote share over time across the sample

the disposable Gini or post-tax Gini, as opposed to the market Gini, since this is a more suitable measure for the inequality that citizens experience and perceive in their daily lives and are most likely to base their reactions on. As previously outlined in our theoretical section, we expected a significant negative effect of a higher Gini, i.e., higher inequality, on voter turnout.

Control Variables Where possible, we controlled for a range of institutional, electoral, and economic variables that have frequently been found to influence voter turnout (Blais 2006; Cancela and Geys 2016; Geys 2006). Regarding institutions, we included variables for compulsory voting and the (dis)proportionality of the electoral system, as well as for presidentialism and bicameralism. Compulsory voting has repeatedly been shown to increase voter turnout; this is accounted for through a simple dummy. Conversely, majoritarian electoral systems exhibit lower turnout rates (Bowler et al. 2001; Jackman 1987; Jackman and Miller 1995) due to their tendency to produce safe seats with limited competitiveness of the local race, providing little incentive for voters to turn out (Selb 2008). In addition, the convergence of party positions around the median voter leads to less ideological distinctiveness and subsequently lower voter motivation to turn out (Cox 1999). This stands in contrast to systems with proportional representation that "waste" fewer votes and make local races always competitive (Blais and Carty 1990; Selb 2008). To account for these institutional differences, we included the Gallagher index in our model, which measures an electoral system's relative disproportionality between votes received and seats allotted in a legislature. Another significant difference exists between parliamentary and presidential systems and the degree of bicameralism, each feeding into voters' cost-benefit calculus of weighing the importance of an election against the costs of the effort to turn out at the ballot box (Blais and Dobrzynska 1998; 
Jackman and Miller 1995). To control for this, we included a dummy variable for presidentialism and an index of bicameralism (Lijphart 2012).

In addition to these "rules of the political game," we accounted for two election-specific factors. First, the effective number of parties has been found to reduce turnout (Blais and Dobrzynska 1998; Jackman and Miller 1995) since a higher number of parties requires the building of coalitions, making elite negotiations relatively more decisive in the formation of a government than the electoral contest (Powell 2000). Second, the closeness of a given race presumably has a positive influence on turnout since it makes every vote more valuable, influencing both voter calculus and the intensity of party campaigning. We accounted for this by including the (logged) distance between the first and second parties in an election into the model. To account for socioeconomic differences between countries, we included gross domestic product (GDP) per capita and a logged population variable in the model. Due to missing data, we were able to analyze 276 of the 296 elections in 31 countries.

\section{Analysis and Empirical Results}

Analytical Approach Our sample is an unbalanced cross-section time series of aggregated national election data. Various tests have demonstrated that disturbances are heteroskedastic and contemporaneously correlated across observational units. A Hausman test further indicated that a fixed-effects model was more appropriate than a random-effects model. Based on these tests, we ran fixed-effects models (with both country and period fixed effects) and, at the country level, clustered standard errors. This type of specification, of course, makes it impossible to include time-invariant institutional features into the models. For example, country fixed

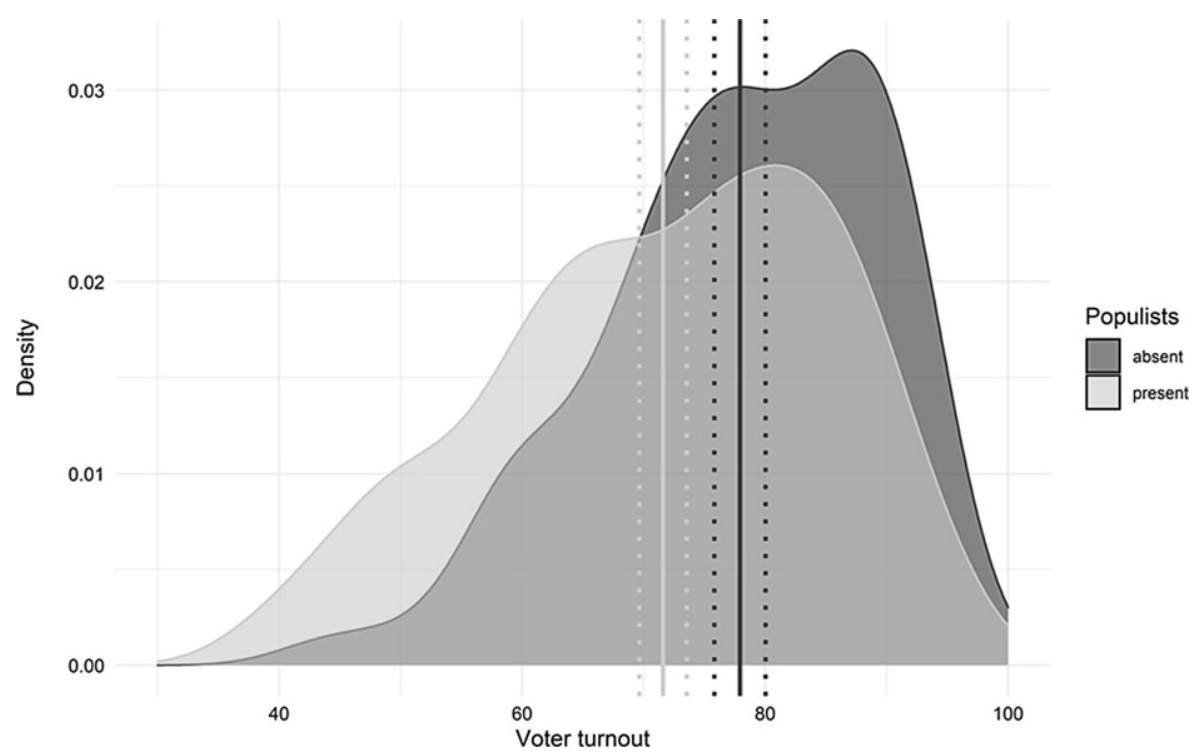

Fig. 3 Distribution of voter turnout with means (solid lines) and 95\% confidence intervals (dotted lines) 
effects will absorb the impact of compulsory voting. However, as we did not seek to establish which institutional factors explain turnout differences, we are confident that our models capture the effect of the theoretically relevant variables (populist vote share, inequality, and their interaction). As we will show, the results are also robust to alternative specifications.

Main Results For a first take on the research question, we looked at descriptive statistics. Figure 3 divides the sample into two groups: elections in which populist parties were competing and elections in which they either did not compete or received an official vote share of zero percent. The solid lines mark the respective mean, while the dotted lines mark $95 \%$ confidence intervals of the mean. This first look at descriptive data casts doubt on the idea that populist parties might increase voter turnout (hypothesis 1). On average, voter turnout was significantly lower in elections where populist parties competed than in those without them. Of course, in the absence of controls this preliminary look might be misleading.

In the next step, we examined whether inequality matters for turnout, as most of the recent literature suggests. Figure 4 shows the bivariate relationship between income inequality and voter turnout, which indicates that the two are negatively related. However, the overall correlation is not very high because many additional factors influence voter turnout $(r=-0.36, p=0.000, N=296)$. For example, if we neglect elections with compulsory voting, Pearson's $r$ drops to -0.47 ( $p=0.000$, $N=253$ ). For a more thorough analysis, we now turn toward multivariate models.

The baseline model is a regression with country and period fixed effects and, at the country level, clustered standard errors (model 1 in Table 2). Contrary to the expectations of hypothesis 1 , the coefficient for populist vote share was negative and statistically insignificant. In contrast, the coefficient of the Gini index of disposable

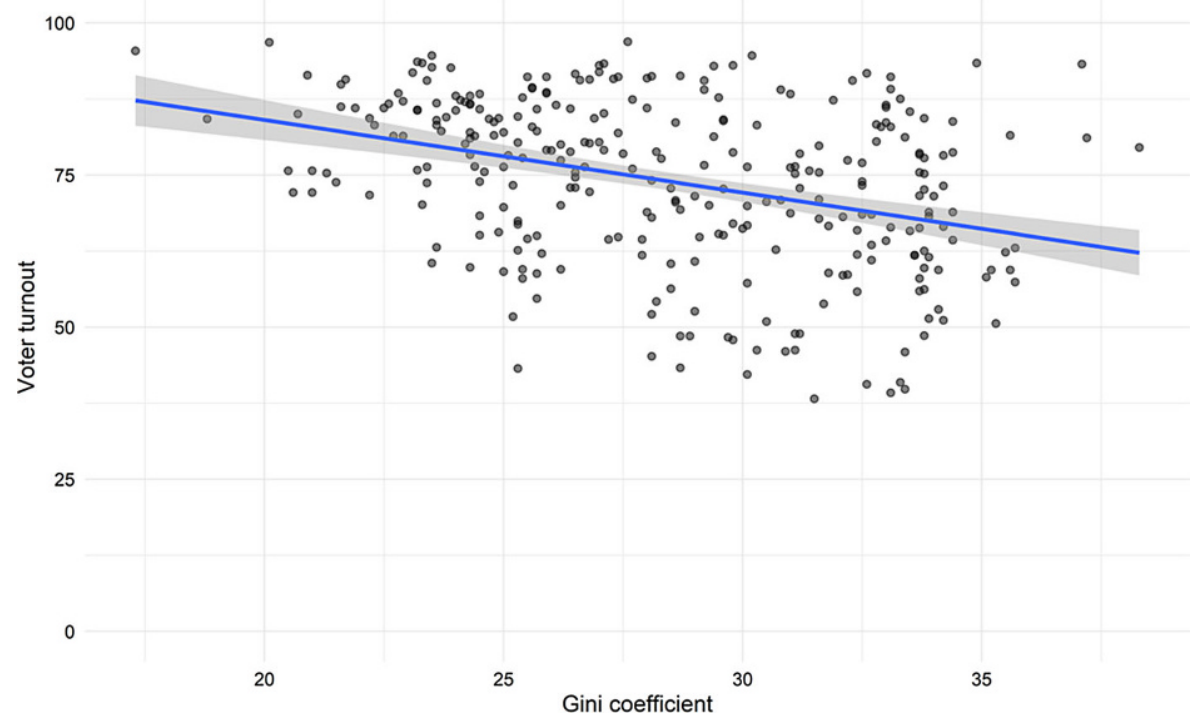

Fig. 4 Covariation of Gini index and voter turnout (fit line with 95\% confidence intervals) 
Table 2 Regression models for voter turnout, inequality, and populist vote share

\begin{tabular}{|c|c|c|c|c|}
\hline \multirow[b]{2}{*}{$\begin{array}{l}\text { Dependent variable: voter } \\
\text { turnout }\end{array}$} & \multicolumn{3}{|c|}{ All populist parties } & \multirow[b]{2}{*}{$\begin{array}{l}\text { Model } 4 \\
\text { (fixed effects) }\end{array}$} \\
\hline & $\begin{array}{l}\text { Model } 1 \\
\text { (fixed effects) }\end{array}$ & $\begin{array}{l}\text { Model } 2 \\
\text { (PCSEs) }\end{array}$ & $\begin{array}{l}\text { Model } 3 \\
\text { (fixed effects) }\end{array}$ & \\
\hline Gini index & $\begin{array}{l}-0.86^{*} \\
(0.35)\end{array}$ & $\begin{array}{l}-1.23 * * * \\
(0.15)\end{array}$ & $\begin{array}{l}-0.85^{*} \\
(0.36)\end{array}$ & $\begin{array}{l}-1.47 * * * \\
(0.34)\end{array}$ \\
\hline Populist vote share & $\begin{array}{l}-0.00 \\
(0.06)\end{array}$ & $\begin{array}{l}-0.10+ \\
(0.06)\end{array}$ & $\begin{array}{l}0.15 \\
(0.41)\end{array}$ & $\begin{array}{l}0.06 \\
(0.37)\end{array}$ \\
\hline Gini * populist vote share & - & - & $\begin{array}{l}-0.00 \\
(0.01)\end{array}$ & $\begin{array}{l}-0.00 \\
(0.01)\end{array}$ \\
\hline $\begin{array}{l}\text { Gallagher index of dispropor- } \\
\text { tionality }\end{array}$ & $\begin{array}{l}-0.10 \\
(0.18)\end{array}$ & $\begin{array}{l}-0.23 \\
(0.15)\end{array}$ & $\begin{array}{l}-0.09 \\
(0.19)\end{array}$ & $\begin{array}{l}-0.30 \\
(0.23)\end{array}$ \\
\hline Effective number of parties & $\begin{array}{l}-1.19 * * \\
(0.39)\end{array}$ & $\begin{array}{l}-1.33^{* *} \\
(0.41)\end{array}$ & $\begin{array}{l}-1.20^{* * *} \\
(0.39)\end{array}$ & $\begin{array}{l}-0.68 \\
(0.47)\end{array}$ \\
\hline $\begin{array}{l}\text { Distance between first and } \\
\text { second parties (logged) }\end{array}$ & $\begin{array}{l}-0.47 \\
(0.43)\end{array}$ & $\begin{array}{l}-0.50 \\
(0.49)\end{array}$ & $\begin{array}{l}-0.50 \\
(0.40)\end{array}$ & $\begin{array}{l}-0.79+ \\
(0.43)\end{array}$ \\
\hline Population (logged) & $\begin{array}{l}11.35 \\
(12.68)\end{array}$ & $\begin{array}{l}0.38 \\
(0.71)\end{array}$ & $\begin{array}{l}10.92 \\
(12.81)\end{array}$ & $\begin{array}{l}35.93 * \\
(13.67)\end{array}$ \\
\hline GDP per capita (logged) & $\begin{array}{l}-6.22^{* * * *} \\
(1.45)\end{array}$ & $\begin{array}{l}-0.19 \\
(1.13)\end{array}$ & $\begin{array}{l}-6.21 * * * \\
(1.46)\end{array}$ & $\begin{array}{l}-6.88^{* * * *} \\
(1.62)\end{array}$ \\
\hline Compulsory voting & - & $\begin{array}{l}15.07 * * * \\
(2.04)\end{array}$ & - & - \\
\hline Bicameralism & - & $\begin{array}{l}-2.23 \\
(1.82)\end{array}$ & - & - \\
\hline Presidentialism & - & $\begin{array}{l}-4.41 * \\
(2.15)\end{array}$ & - & - \\
\hline Country fixed effects & Yes & No & Yes & Yes \\
\hline Period fixed effects & Yes & Yes & Yes & Yes \\
\hline Constant & $\begin{array}{l}61.73 \\
(112.18)\end{array}$ & $\begin{array}{l}121.06^{* * * *} \\
(14.62)\end{array}$ & $\begin{array}{l}65.18 \\
(112.81)\end{array}$ & $\begin{array}{c}-136.67 \\
(117.71)\end{array}$ \\
\hline$R^{2}$ & 0.55 & 0.81 & 0.55 & 0.61 \\
\hline$N$ (elections) & 276 & 270 & 276 & 179 \\
\hline$N$ (countries) & 31 & 31 & 31 & 28 \\
\hline
\end{tabular}

Standard errors in parentheses; throughout this article, we use the Gini index of disposable household incomes

Model 1: Fixed-effects regression with, at the country level, clustered standard errors

Model 2: Random-effects regression with, at the country level, clustered standard errors

Model 3: Prais-Winsten regression, correlated PCSEs

Model 4: Fixed-effects regression with, at the country level, clustered standard errors

Model 5: Fixed-effects regression with, at the country level, clustered standard errors and populist vote share $>0$

PCSEs panel-corrected standard errors

$+p<0.1, * p<0.05, * * p<0.01, * * * p<0.001$

incomes was statistically significant and negative. We can thus confirm that turnout was lower in countries that are more unequal. Neither disproportionality nor the closeness of the election nor population size had a significant impact on voter turnout. The effective number of parties had, somewhat surprisingly, a negative influence. The same holds true for GDP per capita, which could suggest that as 
countries have grown richer, turnout has declined. In these fixed-effects models, we cannot test institutional features, as these are time-invariant.

In the second model, we therefore used a somewhat less restrictive model and eschewed country fixed effects. Instead, we ran a Prais-Winston regression model with panel-corrected standard errors. This model confirmed the negative effect of inequality on turnout. The coefficient for the populist vote share stayed negative and approached statistical significance. Other results were in line with the previous model, with the exception of GDP per capita, which was no longer significant once we introduced institutional factors to the model. Compulsory voting had a strong and significant effect on turnout, bicameralism had no measurable effect, and voter turnout in parliamentary elections was significantly lower in presidential systems. By and large, this second model confirmed the results of the first one.

Based on the evidence so far, we cannot confirm hypothesis 1 . Neither bivariate nor multivariate analyses showed a significant effect of the populist vote share on voter turnout. This is a noteworthy finding because it has been assumed that populist parties will mobilize formerly excluded groups and, thus, lessen participatory inequality. Yet we found no evidence of this effect.

Let us now turn to the second hypothesis, which states that populist parties' success will moderate the negative effect of income inequality on voter turnout.

Models 3 and 4 in Table 2 test the expectation that the populist vote share affects the relationship between inequality and voter turnout. In the first case, we used all the elections, whereas in the second one we restricted the analysis to those where populist parties were present. However, in both cases the interaction effect failed to reach statistical significance. To facilitate interpretation, we illustrated the interaction

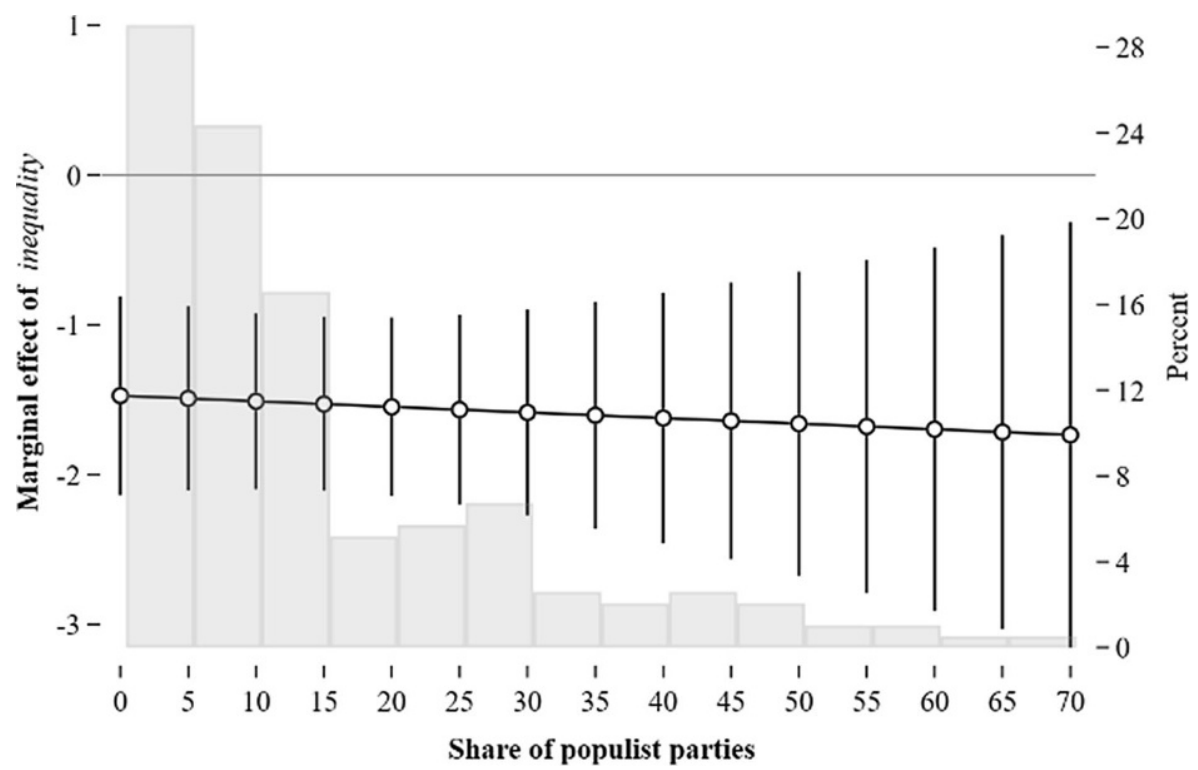

Fig. 5 Average marginal effects on voter turnout with $95 \%$ confidence intervals. Based on model 5 in Table 2 
effect graphically in Fig. 5 as recommended by Brambor et al. (2006, p. 73). The graph also provides information about the distribution of populist vote share in the form of a histogram. In contradiction to the first hypothesis, the average marginal effect of inequality declined slightly as the populist vote share rose-and it was always negative. With a higher vote share of populist parties, the confidence intervals increased, as there were fewer observations. Looking at the combined vote share of right-wing and left-wing populist parties does not support the assumption that these parties alleviate the negative effect of inequality on voter turnout. Therefore, we also reject hypothesis 2 .

In a next step, we examined whether there was a moderating effect of populism on the effect of inequality on turnout for one of the "flavors" of populism. As outlined in the theoretical framework, there are reasons to assume that both left-wing and rightwing populist parties raise voter turnout. We therefore ran the analyses separately for left-wing and right-wing populism. To do so, we ran models 1, 4, and 5 of Table 2 separately for both variants of populism. We do not report the results for the control variables, as these were in line with those in Table 2. If we look at rightwing populist parties only, we again do not see a significant effect of their vote share on voter turnout (model 1a, Table 3). For this subsample, too, the coefficient of income inequality is statistically significant and negative. However, once we introduce the interaction effect (model 1b), the populist party coefficient reaches

Table 3 Variants of populism and voter turnout

\begin{tabular}{lllllll}
\hline & \multicolumn{2}{l}{ Right-wing populist parties } & \multicolumn{2}{l}{ Left-wing populist parties } \\
$\begin{array}{l}\text { Dependent variable: } \\
\text { voter turnout }\end{array}$ & Model 1a & Model 1b & Model 1c & Model 2a & Model 2b & Model 2c \\
\hline Gini index & $-0.97 * *$ & $-0.91^{*}$ & $-1.57 * * *$ & $-0.83^{*}$ & $-0.83^{*}$ & $-0.99+$ \\
& $(0.34)$ & $(0.35)$ & $(0.36)$ & $(0.32)$ & $(0.32)$ & $(0.55)$ \\
Populist vote share & 0.07 & $0.70^{*}$ & -0.05 & $-0.33^{* * *}$ & -0.48 & 0.43 \\
& $(0.06)$ & $(0.27)$ & $(0.50)$ & $(0.08)$ & $(0.45)$ & $(0.74)$ \\
Gini * populist vote share & - & $-0.02^{*}$ & 0.00 & - & 0.00 & -0.03 \\
& & $(0.01)$ & $(0.02)$ & & $(0.02)$ & $(0.02)$ \\
Country fixed effects & Yes & Yes & Yes & Yes & Yes & Yes \\
Period fixed effects & Yes & Yes & Yes & Yes & Yes & Yes \\
Constant & 45.98 & 59.37 & -189.92 & 36.31 & 35.95 & -7.88 \\
& $(99.27)$ & $(100.72)$ & $(143.34)$ & $(96.69)$ & $(96.31)$ & $(86.20)$ \\
$R^{2}$ & 0.55 & 0.55 & 0.64 & 0.58 & 0.58 & 0.44 \\
$N$ (elections) & 276 & 276 & 148 & 276 & 276 & 57 \\
$N$ (countries) & 31 & 31 & 25 & 31 & 31 & 13 \\
\hline
\end{tabular}

All the models include the same variables as model 1 in Table 2. However, we only report those coefficients that are relevant to the theoretical argument. Throughout this article, we use the Gini index of disposable household incomes

Models 1a and 1b: Fixed-effects regression with, at the country level, clustered standard errors

Model 1c: Fixed-effects regression with, at the country level, clustered standard errors and populist vote share $>0$

Models 2a and 2b: Fixed-effects regression with, at the country level, clustered standard errors

Model 2c: Fixed-effects regression with, at the country level, clustered standard errors and populist vote share $>0$

Standard errors in parentheses

$+p<0.1, * p<0.05, * * p<0.01, * * * p<0.001$ 
a $1-$

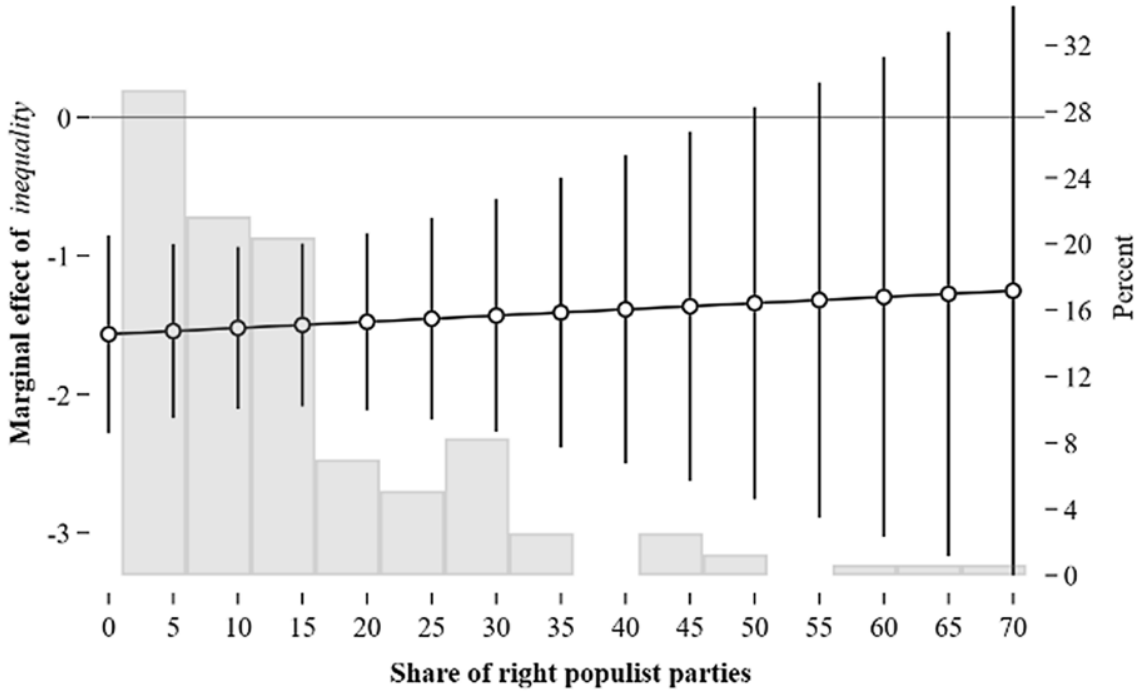

b 1 -

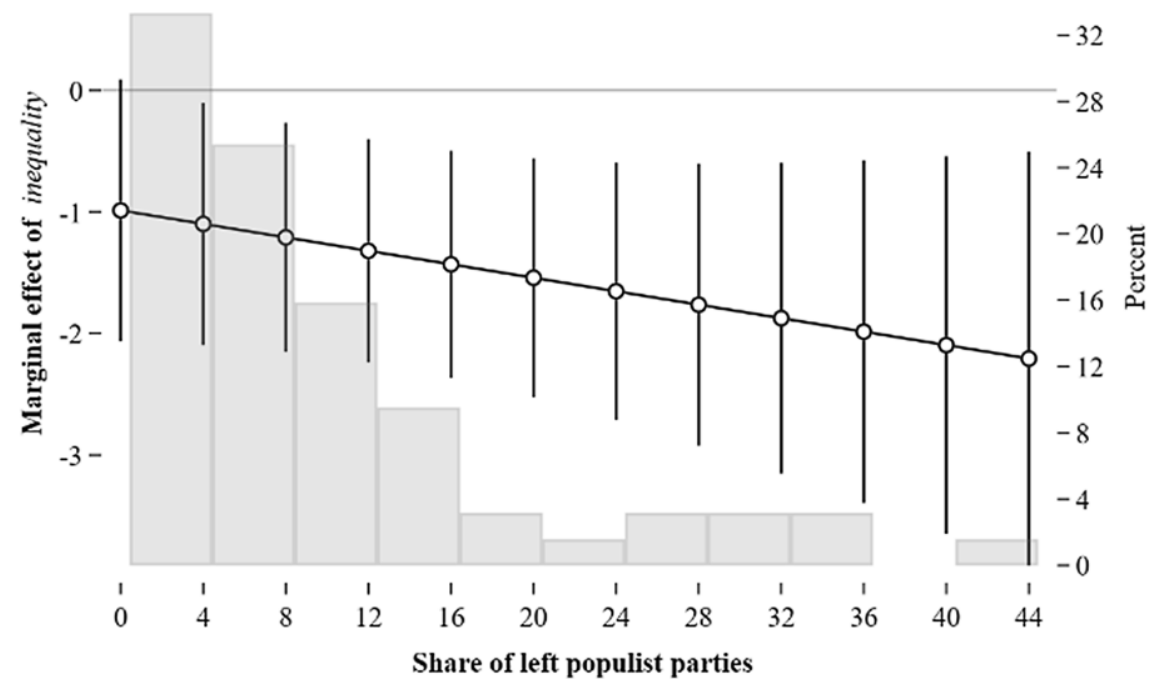

Fig. 6 Average marginal effects of Gini (disposable incomes) on voter turnout with 95\% confidence intervals, differentiating between right-populist (a) and left-populist vote share (b)

statistical significance and the interaction term is negative and significant, which suggests that with greater right-wing populist parties' success, the negative effect of inequality on turnout increases. However, if we restrict the subsample to those elections where populist parties were present at all, the effect disappears (model 1c).

Based on model 3a in Table 3, the left panel of Fig. 6 shows that the negative effect of inequality on turnout was almost constant across different rates of success 
for right-wing populist parties. With fewer cases at high values of the moderator variable, the confidence intervals increase, and the marginal effect of inequality is no longer statistically significant.

The results of left-wing populist parties are similar. However, the coefficient for their vote share in model $2 \mathrm{a}$ of Table 3 is statistically significant and negative, which means that turnout was lower in elections where these parties did well. The interaction effect is insignificant for both variants of the analysis (model $2 b$ and $2 c$ ). The right-hand panel in Fig. 6 shows that, if anything, left-wing populist parties' success might exacerbate the effect of inequality on turnout. As there are relatively fewer cases above $20 \%$, however, we do not want to stress this effect too strongly. Again, different models did not confirm that populist parties reduce the negative impact of inequality on turnout, which implies that hypothesis 3 has to be rejected, too.

In the final step of the analysis, we asked whether it was the fact of being in government rather than populist parties' electoral strength that increases voter turnout. If poorly represented and excluded citizens see that nonmainstream parties claiming to speak for them actually govern, they might be motivated to vote. In contrast, citizens who dislike populist parties might equally be prompted to cast their votes. Hence, with populist parties in government, turnout might increase. Until now, however, relatively few populist parties have made it into government. In our data, there are only 26 elections with populist incumbents. Still, it is possible to reproduce the analyses with a dummy variable "populist party in government." The two models in Table 4 include the same set of variables as before, even though we only report the coefficients for the three variables of interest. The coefficient of income inequality is unaffected, while there is a positive and, at the $10 \%$ level, significant effect of populist incumbency on turnout (model 1, Table 4). The interaction term of inequality and populists in government (model 2, Table 4) is also positive and close

Table 4 Populists in government and voter turnout

\begin{tabular}{lll}
\hline Dependent variable: voter turnout & Model 1 & Model 2 \\
\hline Gini index & $-0.85^{*}$ & $-0.84^{*}$ \\
& $(0.34)$ & $(0.34)$ \\
Populist party in government & $3.19+$ & -14.83 \\
& $(1.87)$ & $(9.18)$ \\
Gini * populist party in government & - & $0.61+$ \\
& & $(0.34)$ \\
Country fixed effects & Yes & Yes \\
Period fixed effects & Yes & Yes \\
Constant & 39.24 & 13.39 \\
& $(110.60)$ & $(115.29)$ \\
$R^{2}$ & 0.56 & 0.57 \\
$N$ (elections) & 276 & 276 \\
$N$ (countries) & 31 & 31 \\
\hline
\end{tabular}

Throughout this article, we use the Gini index of disposable household incomes

Standard errors in parentheses

$+p<0.1, \quad * p<0.05$,

$* * p<0.01$, 
to statistical significance, which suggests that the negative effect of inequality on turnout is small if populist parties govern. The average marginal effect of income inequality turns indistinguishable from zero for cases when populist parties are in government but is statistically significant and negative otherwise. In that sense, there might be a positive effect of populism in terms of electoral turnout.

\section{Conclusion}

There is an ever-growing number of empirical studies analyzing various aspects of populism. At the same time, it is still debated whether populist parties are good for or detrimental to democracy. One argument for why these parties might have beneficial consequences is that they might ameliorate political inequality. In many countries, voter turnout and other forms of political participation are highly unequal. If populists were to mobilize some of the former nonvoters, not only might overall turnout increase but the social turnout differential might decrease at the same time. Because inequalities of electoral participation are particularly large in countries that have higher levels of income inequality, one could assume that populist success might reduce the negative effect of economics on political inequality. However, the empirical evidence provided in this article does not support the idea that populist parties have a positive effect on voter turnout.

In this article, we analyzed 296 elections in 31 countries between 1970 and 2016 and tested whether there was a correlation between populist parties' electoral success and voter turnout. The results showed that there was neither a direct nor an indirect effect of populism on voter turnout. In elections with more successful populist parties, voter turnout was not significantly higher than in other elections. Higher vote shares of populist parties also did not mitigate the negative impact of income inequality on voter turnout. Although the marginal effect of the former on the latter turned out to be insignificant with very high populist vote shares, this is probably due to the low number of observations. There did not seem to be a difference between elections with high left-wing or right-wing populist parties' success. Neither variant of populism altered the relationship between inequality and turnout. Finally, populist parties being in government might make a difference. With populist incumbents, turnout seemed to be somewhat higher, and the negative effect of inequality vanished. However, these results were not significant at conventional levels and were based on only 26 elections; we should, therefore, take them with a grain of salt.

Although we have only analyzed electoral participation, for this particular case we cannot subscribe to the point of view that populism has positive effects for democracy. This does not rule out the possibility that populist parties improve policy representation or congruence between parliamentarians and citizens, or lead to higher levels of political interest or participation beyond elections. These possible implications are beyond the focus of this article. Yet for the most basic form of political participation in a democracy_voting_-populist parties do not make a difference. Thus, our findings relate to recent insights from the research on the populist electorate, particularly the electorate of right-wing populist voters. This literature finds 
that - in contrast to earlier arguments - the main voters of right-wing populist parties are not predominantly the disadvantaged or "losers of modernization" but rather those who fear loss in the future (Burgoon et al. 2019; Schwander and Manow 2017). Fear of social decline rather than actual social decline seems to trigger a populist vote. In that case, populist parties do not (even) mobilize politically alienated social groups and can therefore not offset the impact of inequality on turnout.

Acknowledgements We would like to thank two anonymous reviewers for very constructive comments that greatly helped to improve this article. Arndt Leininger provided very helpful comments for an earlier version of this article.

Funding Open Access funding provided by Projekt DEAL.

Open Access This article is licensed under a Creative Commons Attribution 4.0 International License, which permits use, sharing, adaptation, distribution and reproduction in any medium or format, as long as you give appropriate credit to the original author(s) and the source, provide a link to the Creative Commons licence, and indicate if changes were made. The images or other third party material in this article are included in the article's Creative Commons licence, unless indicated otherwise in a credit line to the material. If material is not included in the article's Creative Commons licence and your intended use is not permitted by statutory regulation or exceeds the permitted use, you will need to obtain permission directly from the copyright holder. To view a copy of this licence, visit http://creativecommons.org/licenses/by/4. $0 /$.

\section{References}

Abou-Chadi, Tarik, and Werner Krause. 2018. The causal effect of radical right success on mainstream parties' policy positions: a regression discontinuity approach. British Journal of Political Science 41:1-19.

Abou-Chadi, Tarik, and Markus Wagner. 2019. The electoral appeal of party strategies in postindustrial societies: when can the mainstream left succeed? The Journal of Politics 81(4):1405-1419.

Akkerman, Tjitske. 2016. Conclusions. In Radical right-wing populist parties in Western-Europe: Into the mainstream? [eng]. Extremism and democracy, ed. Tjitske Akkerman, Sarah L. de Lange, and Matthijs Rooduijn, 268-282. London, New York: Routledge Taylor \& Francis Grou.

Akkerman, Agnes, Cas Mudde, and Andrej Zaslove. 2013. How populist are the people? Measuring populist attitudes in voters. Comparative Political Studies 47(9):1324-1353.

Anderson, Christopher J., and Pablo Beramendi. 2011. Left parties, poor voters, and electoral participation in advanced industrial societies. Comparative Political Studies 45(6):714-746.

Anduiza, Eva, Marc Guinjoan, and Guillem Rico. 2019. Populism, participation, and political equality. European Political Science Review https://doi.org/10.1017/S1755773918000243.

Arzheimer, Kai. 2009. Contextual factors and the extreme right vote in western Europe, 1980-2002. American Journal of Political Science 53(2):259-275.

Arzheimer, Kai. 2018. Explaining electoral support for the radical right. In The oxford handbook of the radical right, ed. Jens Rydgren, 143-165. New York: Oxford University Press.

Bale, Tim. 2003. Cinderella and her ugly sisters: the mainstream and extreme right in Europe's bipolarising party systems. West European Politics 26(3):67-90.

Bale, Tim, Christoffer Green-Pedersen, André Krouwel, Kurt R. Luther, and Nick Sitter. 2009. If you can't Beat them, join them? Explaining social democratic responses to the challenge from the populist radical right in Western Europe. Political Studies 58(3):410-426.

Bartels, Larry M. 2008. Unequal democracy: the political economy of the new gilded age. Princeton: Princeton University Press.

Betz, Hans-Georg, and Fabian Habersack. 2020. Regional nativism in east Germany: the case of the AfD. In The people and the nation: populism and ethno-territorial politics in europe, ed. Reinhard Heinisch, Emanuele Massetti, and Oscar Mazzoleni, 110-135. Abingdon, Oxon, New York: Routledge.

Blais, André. 2006. What affects voter turnout. American Review of Political Science 9:111-125.

Blais, André, and R.K. Carty. 1990. Does proportional representation foster voter turnout? European Journal of Political Research 18(2):167-181.

Blais, André, and Agnieszka Dobrzynska. 1998. Turnout in electoral democracies. European Journal of Political Research 33(2):239-261. 
Bornschier, Simon. 2010. Cleavage politics and the populist right: The new cultural conflict in Western Europe. Philadelphia: Temple University Press.

Bornschier, Simon. 2012. Why a right-wing populist party emerged in France but not in Germany: cleavages and actors in the formation of a new cultural divide. European Political Science Review 4(1):121-145.

Bornschier, Simon. 2018. Globalization, cleavages and the radical right. In The oxford handbook of the radical right, ed. Jens Rydgren, 212-238. New York: Oxford University Press.

Bowler, Shaun, David Brockington, and Todd Donovan. 2001. Election systems and voter turnout: experiments in the United States. The Journal of Politics 63(3):902-915.

Brady, Henry E. 2004. An analytical perspective on participatory inequality and income inequality. In Social Inequality, ed. Kathryn M. Neckerman, 667-702. New York: SAGE.

Brady, Henry E., Sidney Verba, and Kay L. Schlozman. 1995. Beyond SES: a resource model of political participation. American Political Science Review 89(2):271-294.

Brambor, Thomas William R.Clark, and Matt Golder. 2006. Understanding interaction models: improving empirical analyses. Political Analysis 14(1):63-82.

Burgoon, Brian. 2012. Inequality and anti-globalization backlash by political parties. European Union Politics 14(3):408-435.

Burgoon, Brian, Sam van Noort, Matthijs Rooduijn, Geoffrey Underhill, and Thorsten Beck. 2019. Positional deprivation and support for radical right and radical left parties. Economic Policy 34(97):49-93.

Cancela, João, and Benny Geys. 2016. Explaining voter turnout: a meta-analysis of national and subnational elections. Electoral Studies 42:264-275.

Cox, Gary W. 1999. Electoral rules and the calculus of mobilization. Legislative Studies Quarterly 24(3):387

Davies, Emmerich, and Tulia G. Falleti. 2017. Poor people's participation: neoliberal institutions or left turn? Comparative Political Studies 50(12):1699-1731.

Döring, Holger, and Philip Manow. 2019. Parliaments and governments database (ParlGov): Information on parties, elections and cabinets in modern democracies. Development version. http://www.parlgov. org/. Accessed March 20, 2020.

Elsässer, Lea, Svenja Hense, and Armin Schäfer. 2017. „Dem Deutschen Volke“? Die ungleiche Responsivität des Bundestags. Zeitschrift für Politikwissenschaft 27(2):161-180.

Evans, Geoffrey, and James Tilley. 2017. The new politics of class. Oxford: Oxford University Press.

Fervers, Lukas, and Hanna Schwander. 2015. Are outsiders equally out everywhere? The economic disadvantage of outsiders in cross-national perspective. European Journal of Industrial Relations 21(4):369-387.

Ford, Robert, Matthew J. Goodwin, and David Cutts. 2012. Strategic Eurosceptics and polite xenophobes:support for the United Kingdom Independence Party (UKIP) in the 2009 European Parliament elections. European Journal of Political Research 51(2):204-234.

Gallego, Aina. 2015. Unequal political participation worldwide. Cambridge: Cambridge University Press.

Geys, Benny. 2006. Explaining voter turnout: a review of aggregate-level research. Electoral Studies 25(4):637-663.

Giger, Nathalie, Jan Rosset, and Julian Bernauer. 2012. The poor political representation of the poor in a comparative perspective. Representation 48(1):47-61.

Gilens, Martin. 2005. Inequality and democratic responsiveness. Public Opinion Quarterly https://doi.org/ 10.1093/poq/nfi058.

Gingrich, Jane, and Silja Häusermann. 2015. The decline of the working-class vote, the reconfiguration of the welfare support coalition and consequences for the welfare state. Journal of European Social Policy 25(1):50-75.

Goerres, Achim, Dennis C. Spies, and Staffan Kumlin. 2018. The electoral supporter base of the alternative for Germany. Swiss Political Science Review 24(3):246-269.

Gurr, Ted R. 1970. Why men rebel. Published for the center of international studies. Princeton: Princeton University [by] Princeton University Press.

Hacker, Jacob S., Philipp Rehm, and Mark Schlesinger. 2013. The insecure American: economic experiences, financial worries, and policy attitudes. Perspectives on Politics 11(1):23-49.

Hainmueller, Jens, and Michael J. Hiscox. 2007. Educated preferences: explaining attitudes toward immigration in europe. International Organization 61(02):47.

Halikiopoulou, Daphne, Kyriaki Nanou, and Sofia Vsdilopoulou. 2012. The paradox of nationalism: the common denominator of radical right and radical left euroscepticism. European Journal of Political Research 51(4):504-539. 
Häusermann, Silja. 2018. Social democracy and the welfare state in context: the conditioning effect of institutional legacies and party competition. In Welfare democracies and party politics: explaining electoral dynamics in times of changing welfare capitalism, ed. Philip Manow, Bruno Palier, and Hanna Schwander, 150-170. Oxford: Oxford University Press.

van Hauwaert, Steven M., and Stijn van Kessel. 2018. Beyond protest and discontent: A cross-national analysis of the effect of populist attitudes and issue positions on populist party support. European Journal of Political Research 57(1):68-92.

Hooghe, Liesbet, Gary Marks, and Carole J. Wilson. 2004. Does left/right structure party positions on European integration? In European integration and political conflict, ed. Gary Marks, Marco R. Steenbergen, 120-140. Cambridge: Cambridge University Press.

Hooghe, Marc, Sofie Marien, and Teun Pauwels. 2011. Where do distrusting voters turn if there is no viable exit or voice option? The impact of political trust on electoral behaviour in the Belgian regional elections of June 2009. Government and Opposition 46(2):245-273.

Huber, Evelyne, and John D. Stephens. 2001. Development and crisis of the welfare state: parties and policies in global markets

Immerzeel, Tim, and Mark Pickup. 2015. Populist radical right parties mobilizing 'the people'? The role of populist radical right success in voter turnout. Electoral Studies 40:347-360.

Ivarsflaten, Elisabeth. 2007. What unites right-wing populists in western Europe? Comparative Political Studies 41(1):3-23.

Jackman, Robert W. 1987. Political institutions and voter turnout in the industrial democracies. American Political Science Review 81(2):405-423.

Jackman, Robert W., and Ross A. Miller. 1995. Voter turnout in the industrial democracies during the 1980s. Comparative Political Studies 27(4):467-492.

Karreth, Johannes, Jonathan T. Polk, and Christopher S. Allen. 2013. Catchall or catch and release? The electoral consequences of social democratic parties' march to the middle in western Europe. Comparative Political Studies 46(7):791-822.

Kitschelt, Herbert. 1994. The transformation of European social democracy. Cambridge: Cambridge University Press.

Krause, Werner, and Aiko Wagner. 2019. Becoming part of the gang? Established and nonestablished populist parties and the role of external efficacy. Party Politics https://doi.org/10.1177/ 1354068819839210.

Kriesi, Hanspeter. 1998. The transformation of cleavage politics: the 1997 Stein Rokkan Lecture. European Journal of Political Research 33(2):165-185.

Kriesi, Hanspeter. 2008a. West European politics in the age of globalization. Cambridge: Cambridge University.

Kriesi, Hanspeter, Edgar Grande, Romain Lachat, Martin Dolezal, Simon Bornschier, and Timotheos Frey. 2008b. West European politics in the age of globalization. Cambridge: Cambridge University Press.

Lijphart, Arend. 2012. Patterns of democracy: government forms and performance in thirty-six countries, 2nd edn., New Haven: Yale University Press.

Lindbeck, Assar, and Dennis J. Snower. 2001. Insiders versus outsiders. Journal of Economic Perspectives 15(1):165-188.

Lubbers, Marcel, and Peer Scheepers. 2007. Explanations of political Euro-Scepticism at the individual, regional and national levels. European Societies 9(4):643-669.

Lubbers, Marcel, Merove Gijsberts, and Peer Scheepers. 2002. Extreme right-wing voting in Western Europe. European Journal of Political Research 41(3):345-378.

Lutz, Philipp. 2019. Variation in policy success: radical right populism and migration policy. West European Politics 42(3):517-544.

Mahler, Vincent A. 2002. Exploring the subnational dimension of income inequality: an analysis of the relationship between inequality and electoral turnout in the developed countries. International Studies Quarterly 46(1):117-142.

Manow, Philip. 2018. Die politische Ökonomie des Populismus. Vol. 2728. Berlin: Suhrkamp.

Meltzer, Allan H., and Scott F. Richard. 1981. A rational theory of the size of government. Journal of political economy 89(5):914-927.

Mény, Yves, and Yves Surel. 2002. The constitutive ambiguity of populism. In Democracies and the populist challenge, ed. Yves Mény, Yves Surel, 1-21. London: Palgrave Macmillan.

Mosimann, Nadja. 2017. Solidarity in times of inequality: trade union politics and union membership effects. PhD thesis. Genève: Université de Genève.

Mouffe, Chantal. 2005. The 'end of politics' and the challenge of right-wing populism. In Populism and the mirror of democracy, ed. Francisco E. Panizza, 72-98. London, New York: Verso. 
Mouffe, Chantal. 2018. For a left populism. London, New York: Verso.

Mudde, Cas. 2004. The Populist Zeitgeist. Government and Opposition 39(4):541-563.

Mudde, Cas, and Cristóbal R. Kaltwasser. 2012. Populism and (liberal) democracy: a framework for analysis. In Populism in Europe and the Americas, ed. Cas Mudde, Cristobal Rovira Kaltwasser, 1-26. Cambridge: Cambridge University Press.

Mudde, Cas, and Cristóbal Rovira Kaltwasser. 2013. Exclusionary vs. Inclusionary populism: comparing contemporary Europe and latin America. Government and Opposition 48(2):147-174.

Mudde, Cas, and Cristóbal Rovira Kaltwasser. 2017. Populism: a very short introduction. Vol. 510. Oxford, New York: Oxford University Press.

Norris, Pippa, and Ronald Inglehart. 2019. Cultural backlash: Trump, Brexit, and authoritarian populism. Cambridge: Cambridge University Press.

OECD. 2008. Growing unequal?: income distribution and poverty in OECD countries. Paris: Organisation for Economic Co-operation and Development.

OECD. 2011. Divided we stand: why inequality keeps rising. Paris: OECD Publishing.

Oesch, Daniel. 2008. Explaining workers' support for right-wing populist parties in western europe: evidence from Austria, Belgium, France, Norway, and Switzerland. International Political Science Review 29(3):349-373.

Oesch, Daniel, and Line Rennwald. 2010. The class basis of Switzerland's cleavage between the new left and the populist right. Swiss Political Science Review 16(3):343-371.

Oliver, J.E. 2001. Democracy in suburbia. Princeton: Princeton University Press.

Peters, Yvette, and Sander J. Ensink. 2015. Differential responsiveness in europe: the effects of preference difference and electoral participation. West European Politics 38(3):577-600.

Piketty, Thomas. 2014. Capital in the twenty-first century. Cambridge: Belknap Press of Harvard Univ. Press.

Powell, G.B. 2000. Elections as instruments of democracy. Majoritarian and proportional visions. New Haven, London: Yale University Press.

Rennwald, Line, and Geoffrey Evans. 2014. When supply creates demand: social democratic party strategies and the evolution of class voting. West European Politics 37(5):1108-1135.

Rooduijn, Matthijs. 2018. What unites the voter bases of populist parties? Comparing the electorates of 15 populist parties. European Political Science Review 10(3):351-368.

Rooduijn, Matthijs, and Tjitske Akkerman. 2015. Flank attacks: populism and left-right radicalism in western Europe. Party Politics 23(3):193-204.

Rooduijn, Matthijs, Brian Burgoon, Erika J. van Elsas, and Herman G. van de Werfhorst. 2017. Radical distinction: support for radical left and radical right parties in Europe. European Union Politics 18(4):536-559.

Rooduijn, Matthijs, Stijn van Kessel, Caterina Froio, Andrea Pirro, Sarah de Lange, Daphne Halikiopoulou, Paul L. Taggart, and Cas Mudde. 2020. PopuList: An Overview of Populist, Far Right, Far Left and Eurosceptic Parties in Europe. https://popu-list.org.

Röth, Leonce, Alexandre Afonso, and Dennis C. Spies. 2018. The impact of populist radical right parties on socio-economic policies. European Political Science Review 10(3):325-350.

Rueda, David. 2007. Social democracy inside out: Partisanship and labor market policy in industrialized democracies. Oxford, New York: Oxford University Press.

Rydgren, Jens. 2008. Immigration sceptics, xenophobes or racists? Radical right-wing voting in six West European countries. European Journal of Political Research 47(6):737-765.

Schäfer, Armin, and Hanna Schwander. 2019. 'Don't play if you can't win': does economic inequality undermine political equality? European Political Science Review 11(3):395-413.

Schattschneider, Elmer E. 1960. The semisovereign people: a realist's view of democracy in America. Hinsdale: The Dryden Press.

Schumacher, Gijs, and Matthijs Rooduijn. 2013. Sympathy for the 'devil'? Voting for populists in the 2006 and 2010 Dutch general elections. Electoral Studies 32(1):124-133.

Schwander, Hanna. 2019. Are social democratic parties insider parties? Electoral strategies of social democratic parties in Western Europe in the age of dualization. Comparative European Politics 17(5):714-737.

Schwander, Hanna, and Philip Manow. 2017. It's not the economy, stupid! Explaining the electoral success of the German right-wing populist AfD. CIS Working Paper, 94.

Selb, Peter. 2008. A deeper look at the proportionality-turnout nexus. Comparative Political Studies 42(4):527-548.

Shapiro, Ian. 2002. Why the poor don't soak the rich. Daedalus 131(1):118-128. 
Smeeding, Timothy M. 2005. Public policy, economic inequality, and poverty: the United States in comparative perspective. Social Science Quarterly 86(s1):955-983.

Solt, Frederick. 2008. Economic inequality and democratic political engagement. American Journal of Political Science 52(1):48-60.

Solt, Frederick. 2019. Measuring income inequality across countries and over time: the standardized world income inequality database: SWIID version 8.0, february 2019

Stockemer, Daniel, and Lyle Scruggs. 2012. Income inequality, development and electoral turnout-new evidence on a burgeoning debate. Electoral Studies 31(4):764-773.

Verba, Sidney. 1996. The citizen as respondent: sample surveys and American democracy presidential address, American political science association, 1995. American Political Science Review 90(1):1-7.

Visser, Mark, Marcel Lubbers, Gerbert Kraaykamp, and Eva Jaspers. 2014. Support for radical left ideologies in Europe. European Journal of Political Research 53(3):541-558.

Werts, Han, Peer Scheepers, and Marcel Lubbers. 2012. Euro-scepticism and radical right-wing voting in Europe, 2002-2008: Social cleavages, socio-political attitudes and contextual characteristics determining voting for the radical right. European Union Politics 14(2):183-205.

Weyland, Kurt. 2001. Clarifying a contested concept: populism in the study of latin American politics. Comparative Politics 34(1):1-22. 